\title{
Can German wine cooperatives compete on quality?
}

\author{
Guenter H. Schamel \\ Free University of Bozen-Bolzano, School of Economics and Management, 39100 Bozen-Bolzano, Italy
}

\begin{abstract}
The paper analyzes how German cooperative wineries compete with private (i.e. non-cooperative) wineries regarding reputation, quality categorization and varietal selection. Among the reasons why German cooperatives lag behind in terms of reputation for quality wine are organization principles of cooperatives and the difficulty to manage growers supplying grapes of different qualities. Cooperatives turn their supply of grapes into wine often classified as quality wine without much distinction. Conversely, privately owned wineries growing their own grapes may have more control over quality along their production chain and are able to produce more distinctive wines. In turn, they gain more reputation with final consumers with respect to quality. We analyze data for private and cooperative wineries from Germany. Our objective is to identify key differences in terms of reputation for quality wine production. Specifically, we look at interaction effects based on organizational form (cooperative vs. private) and the German wine quality categorization (i.e. basic quality wine vs. Kabinett, Spätlese, or Auslese) as well as varietal effects. We employ a hedonic pricing model to test the hypothesis that wines produced by private producers receive a reputation premium relative to cooperatives. Moreover, we hypothesize that private wineries receive a price premium relative to cooperatives for other than basic quality wines and distinct varieties such as Riesling and Pinot Noir. The empirical analysis confirms both hypotheses. The estimated coefficients indicate that cooperatives are unable to gain quality premium for most quality categories and gain price premiums only for non-distinct varieties such as Lemberger and Dornfelder. We can argue that German cooperatives are stuck in the low quality corner of the quality and variety spectrum and are currently not able to compete with private wineries in terms of quality. This result supports the observation that cooperatives typically compete on price with their wines being sold in discount stores.
\end{abstract}

\section{Introduction}

Cooperatives represent a form of ownership that can be found concurrently in many countries and markets throughout the world. Concurrently, private firms also operate in these markets [1-3]. In the wine sector, cooperative enterprises are predominant in a number of regions including the Northern Italian regions (i.e. Alto Adige, Trentino and Veneto) where they market as much as $70 \%$ of total production [4]. We also observe other sectors (e.g. apples) where a large share of produce is marketed by farmer-owned cooperatives. In Germany, wine cooperatives have a share of roughly $30 \%$ both in terms of wine production and total vineyard area [5].

In Europe, recent changes in the common agricultural policy addressing cooperatives (or more general producer organizations) have been implemented due to increasing concerns regarding their efficiency (and co-existence) in concentrated downstream food markets [6]. The most recent reforms of the Common Agricultural Policy (CAP) aim to facilitate producer cooperation with the intention to improve the efficiency of the food chain as well as agriculture's competitive position within Europe and internationally. To obtain direct support, cooperatives must engage in value enhancing activities (e.g. through product differentiation, quality management systems, marketing and promotion programs, processing facilities, etc.) that will improve the overall competitiveness of their production activities. In particular, this applies to cooperative wineries in Europe who struggle to compete in the global wine market.
In this paper, we examine German cooperatives and their ability compete in today's wine market. We derive indicators for producer reputation, wine quality and varietal orientation for German wine cooperatives and compare them with privately owned wineries. We employ a hedonic model to test the hypothesis that wines from private wineries receive a reputation premium relative to wines produced by cooperatives and we examine if wines from private wineries receive a price premium for wine quality relative to cooperatives. In a second model, we also analyze if there is any orientation towards specific quality attributes (e.g. QbA, Kabinett, etc. as defined by the German wine law) or towards particular varieties (e.g. Riesling, Dornfelder) due to the organizational form of the winery. In short, the second model tests if private wineries receive a price premium relative to cooperatives for any specific quality attribute and/or variety.

Wines produced and marketed by cooperatives often sell for less than a comparable bottle from a private (noncooperative) winery. One explanation for this may be that cooperatives have a lower reputation for wine quality as they suffer from free-rider or coordination problems which was argued by Pennerstorfer and Weiss [7] and SantosArteaga and Schamel [8]. Assuming comparable wine winemaking skills and management capabilities between different ownership forms, a cooperative's reputation for quality depends crucially on whether its individual members deliver high quality grapes which in turn, determines wine quality sold in the market. In contrast, privately owned wineries may consistently produce higher grape qualities 
and thus gain a higher reputation for quality with final consumers.

In Germany, "quality wine" is classified according to a legally binding standard. Natural alcohol content and ripeness at harvest define the quality category (e.g. Kabinett, Spätlese). Acidity and residual sugar determine the style (e.g. dry). Any appraisal of sensory wine quality is based on subjective impressions. This particular notion of "quality" is adheres to in the German wine law and its regulations. In addition, the EU wine law assigns general conditions that apply to all wine-producing member states, taking common interests as well as national differences into account. For example, EU vineyard areas are divided into climatic zones to help compensate for the climatic variations that affect wine production. Moreover, common quality categories allow for comparisons among member states. Each member state determines the criteria and method of assessment necessary to meet local (and EU) quality standards. In Germany, quality is confirmed or denied by official uniform tests, required by the German Wine Law. Regulations governing quality categories and testing are important components of the law. As described in Sect. 2, out of the official testing procedure, the high scoring wines become eligible to enter a national wine competition administered by the German Agricultural Society (DLG).

The empirical application in this paper distinguishes cooperatives and private wineries in order to discern the impact of ownership structure on prices and quality. We develop a hedonic model which includes a point score that is the basis for the award levels (e.g. bronze, silver, gold or gold extra) as well as wine style (e.g. barrique, dry), color, quality categories (e.g. Kabinett, Spätlese), regional origin (e.g. Baden, Rheingau) and wine varieties (e.g. Riesling, Pinot Noir). We will focus on whether ownership structure has an impact on the estimated implicit prices for German quality wines. Our results indicate that wines from cooperatives tend to receive significantly lower implicit prices for key quality categories and for distinctly known German varietals.

The remaining paper is structured as follows. Section 2 introduces the quality regulation and control scheme for German wines. Section 3 provides a brief literature review while Sect. 4 describes the data and the two models developed. The main results are discussed in Sect. 5 while Sect. 6 gives a summary and concludes.

\section{Quality regulations and control}

German wine producers are required to declare specific quality categories on their labels. The European Union wine law mandates two broad quality categories: table wine and quality wine. Within these quality categories, the German wine law specifies more sub-categories than other EU countries. Standard quality wine (labeled $\mathrm{QbA}$ ) must be made exclusively from German produce, be from an approved grape variety grown in one of the 13 specified wine-growing regions, and reach an existing alcohol content of at least $7 \%$ by volume. However, winemakers are allowed to add sugar to $\mathrm{QbA}$ wines before fermentation to increase the alcohol level of the wine. This so-called chaptalization process is commonly used around the world adding more body to otherwise lighter wines.
The quality wine category has six higher-rated subcategories identified by special quality attributes (labeled QmP). QmP must be from a certain district within a winegrowing region and reach specified natural alcohol content for the region, grape variety and special attribute category. Chaptalization is not allowed. The special attribute categories are subject to additional regulations concerning ripeness, method of harvesting, and marketing. In ascending order of ripeness at harvest the special attribute categories are: Kabinett, Spätlese, Auslese, Beerenauslese (BA), Trockenbeerenauslese (TBA) and Eiswein. A more detailed description of the quality categories can be found in Schamel [9].

The German wine law has been criticized because it neglects quality in the absence of yield limits. Another problem is that sugar content at harvest is the only criteria for quality categorization but the boundaries between sub-categories (e.g. Spätlese or Auslese) are adjusted by region. Thus, higher sugar levels are required for wines from warmer regions (e.g. Baden) relative to the cooler areas (e.g. Nahe). Moreover, some producers choose to declassify wines reasoning that it is better to offer an excellent $\mathrm{QbA}$ rather than a mediocre Kabinett. As the new wine law came into force, modern early-ripening varieties were introduced. Whereas previously, a wine labelled "Auslese" indicated a highly selective harvest in the vineyard and correspondingly high quality, it became much easier to produce high-sugar content "Auslese" from Ortega grapes. Moreover, it became perfectly legal to blend Riesling Auslese with a modern early-ripening variety or to chaptalize a QbA but not a QmP such that the former was not necessarily inferior to the latter. The potential for abuse became immense and the fine name that once attached to "Auslese" was degraded.

In addition to the quality control required by the German wine law, each "quality wine" undergoes a critical, blind, sensory testing procedure based on a five-point scale. Producers submit a registration form on which they must state an array of information including vintage, color (red, white, rosé), special quality attributes, regional origin and vineyard site, and the retail price. A sensory evaluation awarding up to five points or fractions thereof is done for three characteristics (bouquet, taste and harmony). The average of the three characteristics scores determines the wine's point level rating and the Chambers of Agriculture (Landwirtschaftskammern) award bronze, silver and gold medals that require a minimum of $3.5,4$, and 4.5 points, respectively. These medal-winning wines become eligible to enter the annual national wine competition (Bundesweinprämierung) administered by the DLG. The DLG uses a similar testing procedure and the "five-point system" to determine wines of superior quality, which are worthy award medals and prizes. Bronze, silver and gold awards are granted with a minimum of 3.5, 4, and 4.5 points, respectively. In a special competition, Gold Extra Prizes (Goldener Preis Extra) are awarded to wines with a perfect 5-point score. For consumers, medals and DLG awards are a valuable guide to assess wine quality. In the past, the DLG award scheme was criticized for not being rigorous, awarding too many gold medals and in response, a more rigorous judging was introduced which decreased the share of gold medals somewhat. 


\section{Brief literature review}

Only a limited number of studies have looked at the relation between ownership structure and product quality or producer reputation in an analytical way. Since we have motivated the paper arguing that cooperatives may among others face free rider problems in assuring high quality production, we limit our review of the literature to the case of cooperatives and related private firms. For a more complete review of the related literature on hedonic pricing models, cooperatives and quality wine production, we refer to a recent paper by Schamel [4].

Pennerstorfer and Weiss [7] study the impact of decentralized decision making on product quality and conclude that cooperative members have an incentive to overproduce and free-ride on product quality. In their theoretical model, quality provision depends on how quality is aggregated and on the size of the cooperative. Empirically, they find that wines produced by Austrian cooperatives are of significantly lower quality.

Hoffmann [10] derives a simple analytical framework to demarcate ownership structure and quality provision. He assumes a duopoly model to analyze cooperatives vs. investor owned firms (IOF) with simultaneous quality choice and price competition. Depending on the organizational form and whether the cost of quality is assumed to be fixed or variable, a firm can have a cost advantage due to ownership structure in addition to a quality advantage.

Hanf and Schweickert [11] analyze the conflict within wine cooperatives in Germany stemming from member orientation with a focus on quantity and customer (i.e. quality) orientation associated with a saturated and competitive market environment. They outline the difficulties that member owned wine cooperatives face in terms of raising overall quality.

For Germany, it has been shown empirically that depending on producer organization and market environment, considerable price differences exist even between cooperatively produced wines and those from privately owned wineries [12,13]. Schamel [13] estimates that German cooperatives suffer a reputation discount of about $10 \%$ relative to private wineries with the conclusion that they "are lagging behind in terms of strategically addressing the opportunities presented in today's global wine market (i.e. going for varietal wines of high quality with aging potential that are competitive and fetch higher prices)."

In the following section, we set out the data and the empirical analysis to investigate whether German cooperatives are able to compete with private wineries in terms of quality. Private wineries growing their own grapes may experience a lower uncertainty about grape quality relative to cooperatives such that we my hypothesized a price difference due to reputation and/or wine quality. In addition, we study if there are any relative price differences for specific quality attributes (e.g. QbA, Kabinett) and distinct varieties (e.g. Riesling, Dornfelder) between cooperatives and privately owned wineries.

\section{Data and model}

We use a data set of 3593 award winning wines from the annual DLG wine competition (2005 Bundeswein-prämierung).
Table 1. Description of independent variables.

\begin{tabular}{|c|c|}
\hline Variable & Value \\
\hline Cooperative & Cooperative Producer $=1$, Private Producer $=0$ \\
\hline Award Levels & Gold Extra, Gold*, Silver, Bronze \\
\hline Points & min. 3.5 for Bronze Medal, max. 5 for Gold/Gold Extra \\
\hline Age & $1-7$ Years \\
\hline Color & Red Wine $=1$, non-red $=0$ \\
\hline Dry & Dry style $=1$, other style $=0$ \\
\hline Barrique & Barrique style $=1$, non barrique style $=0$ \\
\hline $\begin{array}{l}\text { Quality Category } \\
\text { (Q-Cat) }\end{array}$ & $\begin{array}{l}\text { Qualitätswein (QbA), Kabinett (Kab), Spätlese (Spl)*, } \\
\text { Auslese, Beerenauslese (BA), Trockenbeerenauslese } \\
\text { (TBA), Eiswein }\end{array}$ \\
\hline Region & $\begin{array}{l}\text { Ahr, Baden, Franken, Hess. Bergstr., Mittelrhein, Mosel- } \\
\text { Saar-Ruwer, Nahe, Pfalz*, Rheingau, Rheinhessen, } \\
\text { Saale-Unstrut, Sachsen, Württemberg }\end{array}$ \\
\hline Variety & $\begin{array}{l}\text { Riesling, Gewürztraminer, Chardonnay, Pinot Blanc, } \\
\text { Pinot Noir, Other Varieties*, Dornfelder, Lemberger }\end{array}$ \\
\hline
\end{tabular}

The competition results are published in print as well as online (www. wein.de). In Table 1, definitions of the variables at hand are given while Table 2 lists some summary statistics including wine age, average prices, average point ratings and the distribution of award winning wines between cooperatives and non-cooperatives. We note that the smaller regions receive a more than proportional share of awards.

From the data set, we develop a hedonic model which includes a measure of wine quality based on the point score attained in the DLG wine competition. As control variables, we include wine age, wine style (e.g. barrique, dry), color and regional origin (e.g. Baden, Rheingau). Producers are asked state a retail price per bottle on the registration form before entering the federal competition but after succeeding at the State level. Therefore, the price information used as the dependent variable in the model is pre-competition information and does not reflect any direct effects from winning a federal award.

We estimate two models. The first model estimates whether ownership structure matters in terms of reputation (i.e. if the wine is from a cooperative or not) and price premiums received for wine quality. The second model classifies the main quality categories and wine varieties in Germany. It will analyze the interaction between winery organizational form and the main quality categories and wine varieties. As dependent variable we use the logarithm of the pre-competition retail price $[\log ($ Price $)]$.

Table 2. Key summary statistics.

\begin{tabular}{|l|rr|r|}
\hline & All Wines & Coop-Wines & Non-Coop \\
\hline Average price (min, max) & $8.54 €$ & $8.46 €(2 €, 53 €)$ & $8.59 €(2 €, 99 €)$ \\
Average points (min, max) & 4.17 & $4.21(3.5,5)$ & $4.15(3.5,5)$ \\
Average age (min, max) & 1.6 Years & $1.75(1,4)$ & $1.53(1,7)$ \\
\# Bronze Medals (share) & 1057 & $324(30.7 \%)$ & $733(69.3 \%)$ \\
\# Silver Medals (share) & 1544 & $575(37.2 \%)$ & $969(62.8 \%)$ \\
\# Gold Medals (share) & 992 & $412(41.5 \%)$ & $580(58.5 \%)$ \\
\# Gold Extra Prizes (share) & 45 & $11(24.4 \%)$ & $34(75.6 \%)$ \\
\# Observations (share) & 3593 & $1311(36.5 \%)$ & $2282(63.5 \%)$ \\
\hline
\end{tabular}

Source: DLG, own calculations. 
We employ a log-linear function in our regression and estimate the following equation for Model 1:

$$
\begin{aligned}
\log (\text { price })=\alpha+ & \beta \text { Coop }+\rho \text { Points } \\
+ & \gamma_{1} \text { Age }+\gamma_{2} \text { Dry }+\gamma_{3} \text { Barrique }+\gamma_{4} \\
& \text { Color } \\
+ & \delta_{1 i} Q \text {-Cat }+\delta_{2 j} \text { Region }+\delta_{3 k} \text { Variety }+\varepsilon
\end{aligned}
$$

where $\log$ (price) is the logarithm of the wine price, Coop is a dummy variable indicating if the wine is produced by a cooperative and Points is the point score attained in the DLG wine competition (i.e. individual sensory wine quality). Furthermore, age denotes the age of the wine when it was scored in the competition, Dry and Barrique are wine styles, Color indicates if the wine is a red wine or not, Q-Cat is an indicator of the seven quality category defined in the German wine law, Region delineates the 13 German wine growing regions while Variety designates key wine varieties grown there. The Greek letters refer to the coefficients (implicit prices) to be estimated while $\varepsilon$ is the error term assumed to with a zero mean and uniform variance. Please refer to Table 1 for a more detailed definition of the variables.

We use the first model to test the hypothesis that wines from private wineries receive a price premium relative to wines produced by cooperatives, i.e. whether a cooperative wine sells at a discount. Moreover, we examine if wines from private wineries receive a price premium for wine quality relative to cooperatives, i.e. if the quality premium is lower for cooperatives. According to our expectation formulated in the introduction, consumers face more uncertainty regarding product quality and reputation for cooperatively produced wine. Our a priori expectations are that cooperatives exhibit a higher level of uncertainty about grape quality through vertical quality coordination and thus are in an inferior position to compete with private wineries in terms of wine quality and reputation. Accordingly, we formulate hypotheses 1 :

1. Relative to cooperatives, wines produced by private (non-cooperative) wineries receive a

A reputation premium

B higher wine quality premium.

To test hypothesis 1 .A, we expect a significant but negative coefficient for the cooperative dummy variable which would indicate a negative collective reputation for cooperatives ( $\beta_{1}$ coefficient for cooperatively produced wine). For hypothesis 1.B, we expect a lower quality premium for wine from cooperatives. For this purpose, we split the sample into cooperative and private wineries and look for a significantly different positive coefficient $\beta_{2}$ referring to the wine quality indicator (Points) that is higher in the cooperative subsample.

Given its log-linear functional form, estimating the equation for Model 1 yields implicit price premiums and discounts relative to the contribution of the base category (i.e. a non-dry, non-barrique style, white Spätlese of a nondifferentiated variety that originates from a private winery in the Pfalz region).

We modify our log-linear regression established for Model 1 to estimate the second model with which we analyze possible interaction terms between a winery's organizational form and the seven quality categories (Model 2A) and the six distinct wine varieties (Model 2B) and estimate the following equations:
Model 2A:

$$
\begin{aligned}
\log (\text { price })=\alpha & +\beta_{1 i} \text { Coop }^{*} Q-\text { Cat }+\beta_{2 i} \text { NCoop } * \text { QCAt } \\
& +\rho \text { Points } \\
& +\gamma_{1} \text { Age }+\gamma_{2} \text { Dry }+\gamma_{3} \text { Barrique }+\gamma_{4} \\
& \text { Color } \\
& +\delta_{2 j} \text { Region }+\delta_{3 k} \text { Variety }+\varepsilon
\end{aligned}
$$

Model 2B:

$$
\begin{aligned}
\log (\text { price })=\alpha & +\beta_{1 i} \text { Coop } * \text { Variety }+\beta_{2 i} \text { NCoop } * \text { Variety } \\
& +\rho \text { Points } \\
& +\gamma_{1} \text { Age }+\gamma_{2} \text { Dry }+\gamma_{3} \text { Barrique }+\gamma_{4} \\
& \text { Color } \\
& +\delta_{1 i} \text { Q-Cat }+\delta_{2 j} \text { Region }+\varepsilon
\end{aligned}
$$

where $\operatorname{Coop}^{*} Q$-Cat and $N_{\text {Coop }}^{*} Q$-Cat are interaction terms for the quality categories while Coop*Variety and NCoop $*$ Variety represent interaction terms for distinct varieties depending if the winery is a cooperative or not.

We design the second model to check if there is any orientation towards specific quality attributes (e.g. QbA, Kabinett, etc. as defined by the German wine law) or towards particular wine varieties (e.g. Riesling, Dornfelder) based on the organizational form of the winery. In short, the second model tests if private wineries receive a price premium relative to cooperatives for any specific quality attribute and/or distinct variety.

The second model yields implicit price premiums and discounts relative to the contribution of a base category wine which for Model 2A is a non-dry, non-barrique style, non-differentiated white variety Spätlese from a cooperative in the Pfalz region. For Model 2B, the base category wine is a non-dry, non-barrique style, non-differentiated white variety Spätlese from the Pfalz region. Our expected result is as follows: Private wineries are perceived to be superior both in terms of wine quality and reputation, and therefore will also gain quality category and variety premiums. Accordingly, we formulate the hypotheses B:

2. Relative to cooperatives, wines produced by private (non-cooperative) wineries receive

A quality category premiums
B distinct variety premiums.

In order to confirm hypothesis 2.A and 2.B using Model $2 \mathrm{~A}$ and $2 \mathrm{~B}$ respectively, we expect significantly lower coefficients for all Coop interaction term $\left(\beta_{1 i}\right)$ relative to the NCoop interaction terms $\left(\beta_{2}\right)$.

We tested both model and/or the residuals for normality (Jarque-Bera-Test) and heteroskedasticity (WhiteTest) and do not find any significant problems in the data. We also employed RESET tests which rejected other functional forms.

\section{Estimation Results}

In presenting the results we focus on the variables specifically linked to the hypotheses presented. Thus, we will not discuss in great detail the estimated parameters associated with other control variables that are included in the hedonic model for completeness of the analysis.

The estimation results for Model 1 (Table 3) indicate a significantly negative coefficient for the reputation of wine from cooperatives. The estimated coefficient $(-0.12)$ indicates that they receive a collective reputation discount 
worth about $12 \%$ relative to their local privately owned competitors. Thus, we confirm hypothesis 1.A. Wines coming from private (non-cooperative) producers receive a reputation premium relative to cooperative wines.

Comparing the quality premium, i.e. the Points coefficients in the cooperative and private winery (non-cooperative) subsamples, we find that hypothesis $1 . \mathrm{B}$ is also confirmed. This means that private wineries are able to command a significant quality premium relative to their cooperative competitors (i.e. 0.05 vs. 0.15 comparing the Points coefficients in Table 1). Thus, German cooperatives are not able to obtain a quality premium for their wines relative to private (non-cooperative) wineries.

The remaining results on the control variables listed in Table 1 are mostly in line with previous studies. For example, the dry-style effect (Dry) is relatively consistent across the sub-samples ranging between $11 \%$ and $12 \%$ as is the red wine premium $(17 \%)$. It is interesting to note that barrique-style wine is relatively large (about 54\%). It is also interesting to note that the implicit price for TBA category is higher than for Eiswein category.

From Model 1, we may observe that at least for some quality categories (i.e. Kabinett and BA) and for some

Table 3. Results for Model 1: Dependent Variable: $\log$ (price).

\begin{tabular}{|c|c|c|c|c|c|c|c|c|c|}
\hline \multirow[b]{2}{*}{ Variable } & \multicolumn{3}{|c|}{ All Wines } & \multicolumn{3}{|c|}{ Coop Wines } & \multicolumn{3}{|c|}{ Non-Coop Wines } \\
\hline & Coeff. & t-Stat. & Prob. & Coeff. & $\mathrm{t}$-Stat. & Prob. & Coeff. & t-Stat. & Prob. \\
\hline Constant & $0.99 \ddagger$ & 16.7 & 0 & 1.08 & 12.4 & & $0.94 \ddagger$ & 12.1 & 0 \\
\hline Cooperatives & -0.12 & -9.74 & $\mathbf{0}$ & & & & & & \\
\hline Points & 0.13 ; & 9.09 & $\mathbf{0}$ & 0.05 * & 2.62 & 0 & 0.15 & 8.34 & $\mathbf{0}$ \\
\hline Age & $0.02 *$ & 1.82 & 0.07 & $0.07 \ddagger$ & 4.57 & 0 & 0.00 & -0.12 & 0.90 \\
\hline Dry & $0.11 \ddagger$ & 10.4 & 0 & $0.11 \ddagger$ & 7.19 & 0 & $0.12 \ddagger$ & 8.08 & 0 \\
\hline Barrique & $0.54 \ddagger$ & 25.6 & 0 & $0.57 \ddagger$ & 16.0 & 0 & $0.53 \ddagger$ & 20.0 & 0 \\
\hline Color & 0.17 & 9.9 & 0 & $0.17 \ddagger$ & 6.70 & 0 & $0.17 \ddagger$ & 7.04 & 0 \\
\hline $\mathrm{QbA}$ & $-0.18 \ddagger$ & -14.1 & 0 & -0.19 & -10.6 & 0 & $-0.17 \ddagger$ & -9.79 & 0 \\
\hline Kabinett & $-0.28 \ddagger$ & -21.5 & 0 & -0.25 & -14.4 & 0 & -0.29 & -16.5 & $\mathbf{0}$ \\
\hline Auslese & $0.34 \ddagger$ & 22.1 & 0 & $0.34 \ddagger$ & 15.4 & 0 & $0.35 \ddagger$ & 16.8 & 0 \\
\hline BA & $0.98 \ddagger$ & 25.9 & 0 & $1.07 \ddagger$ & 21.3 & 0 & $0.90 \ddagger$ & 16.4 & $\mathbf{0}$ \\
\hline TBA & $1.48 \ddagger$ & 22.0 & 0 & 1.45 & 21.5 & 0 & $1.54 \ddagger$ & 15.1 & 0 \\
\hline Eiswein & $1.36 \ddagger$ & 43.5 & 0 & $1.37 \pm$ & 31.0 & 0 & $1.35 \ddagger$ & 33.7 & 0 \\
\hline Ahr & $0.58 \ddagger$ & 9.03 & 0 & $0.91 \ddagger$ & 10.8 & 0 & $0.37 \ddagger$ & 6.19 & 0 \\
\hline Baden & $0.35 \ddagger$ & 20.1 & 0 & $0.35 \ddagger$ & 17.1 & 0 & $0.39 \ddagger$ & 12.3 & 0 \\
\hline Franken & $0.40 \ddagger$ & 20.0 & 0 & $0.46 \ddagger$ & 13.3 & 0 & $0.37 \ddagger$ & 15.2 & 0 \\
\hline Hess-Bergstr. & $0.21 \ddagger$ & 5.93 & 0 & $0.22 \ddagger$ & 4.95 & 0 & $0.20 \ddagger$ & 3.69 & 0 \\
\hline Mittelrhein & $0.16 \ddagger$ & 3.53 & 0 & & & & $0.14 \ddagger$ & 2.75 & 0 \\
\hline Mosel & $0.16 \ddagger$ & 7.07 & 0 & & & & $0.14 \ddagger$ & 5.59 & 0 \\
\hline Nahe & $0.23 \ddagger$ & 7.02 & 0 & -0.03 & -0.90 & 0.37 & $0.21 \ddagger$ & 6.10 & 0 \\
\hline Rheingau & $0.31 \ddagger$ & 6.48 & 0 & 0.23 & 1.50 & 0.13 & $0.29 \ddagger$ & 5.84 & 0 \\
\hline Rheinhessen & $-0.07 \ddagger$ & -4.02 & 0 & -0.16 & -2.98 & 0 & $-0.08 \ddagger$ & -4.36 & 0 \\
\hline Saale Un. & $0.44 \ddagger$ & 12.3 & 0 & $0.45 \ddagger$ & 9.41 & 0 & $0.42 \ddagger$ & 9.79 & 0 \\
\hline Sachsen & $0.74 \ddagger$ & 24.2 & 0 & $0.59 \ddagger$ & 11.0 & 0 & $0.74 \ddagger$ & 21.7 & 0 \\
\hline Württemberg & $0.15 \ddagger$ & 8.8 & 0 & $0.19 \ddagger$ & 8.88 & 0 & $0.10 \ddagger$ & 3.74 & 0 \\
\hline Riesling & $0.16 \ddagger$ & 9.09 & 0 & $0.10 \ddagger$ & 3.37 & & $0.16 \ddagger$ & 7.66 & 0 \\
\hline Gewürztr. & $0.16 \ddagger$ & 7.57 & 0 & $0.14 \ddagger$ & 4.69 & & $0.17 \ddagger$ & 5.85 & 0 \\
\hline Chardonnay & $0.12 \ddagger$ & 3.70 & 0 & 0.18 & 3.53 & 0 & $0.09 \dagger$ & 2.28 & 0.02 \\
\hline Pinot Blanc & $0.08 \ddagger$ & 3.87 & 0 & $0.07 *$ & 1.91 & 0.06 & $0.07 \ddagger$ & 2.93 & 0 \\
\hline Pinot Noir & $0.03 *$ & 1.79 & 0.07 & 0.03 & 1.34 & 0.18 & 0.03 & 1.20 & 0.23 \\
\hline Dornfelder & -0.08 & -3.76 & 0 & -0.02 & -0.57 & 0.57 & -0.12 & -3.69 & $\mathbf{0}$ \\
\hline Lemberger & $0.12 \ddagger$ & 4.70 & 0 & 0.13 * & 4.84 & 0 & 0.02 & 0.32 & 0.75 \\
\hline F-statistic & & $332.0^{\ddagger}$ & 0 & & $199.1^{*}$ & & & $187.8 \ddagger$ & \\
\hline Wald F-stat. & & $282.9^{+}$ & 0 & & $198.3^{*}$ & & & $163.5 \ddagger$ & 0 \\
\hline Adjusted $\mathrm{R}^{2}$ & & 0.741 & & & 0.809 & & & 0.711 & \\
\hline Observations & & 3593 & & & 1311 & & & 2282 & \\
\hline
\end{tabular}

Estimation method: LS/White heteroskedasticity-consistent standard errors \& covariance. The symbols $\ddagger, \dagger$, and $*$ denote significance at the $1 \%, 5 \%$, and $10 \%$ level, respectively. varieties (i.e. Chardonnay, Lemberger, Dornfelder) the coefficient in the cooperative subsample is lower than in the non-coop (private winery) subsample. These results warrant further investigation, applying interaction terms as suggested for Model 2.

In Table 4, we list the estimation results for Model 2. Examining the left-hand side, the estimated interaction coefficients for all quality categories (Model 2A) are significant and indicate that relative to wines from a cooperative, private (non-cooperative) wines receive a significantly higher premium for all quality categories (except BA where the Coop*BA coefficient is just slightly larger than the NCoop*BA coefficient). This indicates that we can also confirm hypothesis 2 .A except for one quality category.

Examining the right-hand side of Table 4, which lists the interaction terms of distinct varieties and winery organization., we observe that the estimated coefficients especially for distinctly know German varieties (i.e. Riesling and also Pinot Noir) are significantly larger for private producers. Only for two lesser known varieties (Lemberger a.k.a. Blaufränkisch and Dornfelder), cooperative wineries

Table 4. Results for Model 2: Dependent Variable: $\log$ (price).

\begin{tabular}{|c|c|c|c|c|c|c|}
\hline \multicolumn{4}{|c|}{ 2.A Quality Category Interaction } & \multicolumn{3}{|c|}{ 2.B Variety Interaction } \\
\hline Variable & Coeff. & $\mathrm{t}-\mathrm{Sta}$ & Prob. & Variable & Coeff. & t-Stat. Prob. \\
\hline Constant & $0.87 \ddagger$ & 14.3 & 0 & Constant & 0.98 & 16.40 \\
\hline Coop*QbA & $-0.17 \ddagger$ & -10.3 & 0 & Coop*Riesling & 0.02 & $0.74 \quad 0.46$ \\
\hline $\mathbf{N C o o p}^{*} \mathbf{Q b A}$ & $-0.06 \ddagger$ & -3.25 & $\mathbf{0}$ & NCoop*Riesling & $0.20 \ddagger$ & $10.7 \quad 0$ \\
\hline Coop*Kabinett & $-0.27 \ddagger$ & -15.4 & 0 & Coop*Pinot Noir & -0.02 & $\begin{array}{ll}-1.01 & 0.31\end{array}$ \\
\hline NCoop*Kabinett & $-0.16 \ddagger$ & -8.75 & $\mathbf{0}$ & NCoop*Pinot Noir & $0.07 \ddagger$ & 3.420 \\
\hline NCoop*Spätlese & $0.13 \ddagger$ & 7.56 & $\mathbf{0}$ & Coop*Pinot Blanc & -0.03 & -0.830 .41 \\
\hline Coop*Auslese & $0.35 \ddagger$ & 16.2 & 0 & NCoop*Pinot Blanc & $0.12 \ddagger$ & 5.310 \\
\hline NCoop*Auslese & $0.47 \ddagger$ & 21.3 & $\mathbf{0}$ & Coop*Dornfelder & -0.10 & -3.480 \\
\hline Coop* $^{*} \mathbf{B A}$ & $1.06 \ddagger$ & 21.3 & $\mathbf{0}$ & NCoop*Dornfelder & $-0.07 \dagger$ & $\begin{array}{lll}-2.46 & 0.01\end{array}$ \\
\hline NCoop*BA & $1.03 \ddagger$ & 19.0 & 0 & Coop*Lemberger & 0.11 & 4.180 \\
\hline Coop*TBA & $1.40 \ddagger$ & 21.4 & 0 & NCoop*Lemberger & 0.04 & 1.070 .28 \\
\hline NCoop*TBA & $1.67 \ddagger$ & 16.3 & $\mathbf{0}$ & Coop*Gewürztr. & $0.05 *$ & $\begin{array}{ll}1.82 & 0.07\end{array}$ \\
\hline Coop*Eiswein & $1.36 \ddagger$ & 30.2 & 0 & NCoop*Gewürztr. & $0.22 \ddagger$ & $8.07 \quad 0$ \\
\hline NCoop*Eiswein & $1.48 \ddagger$ & 36.0 & $\mathbf{0}$ & Coop*Chardonnay & 0.07 & 1.390 .16 \\
\hline Points & $0.13 \ddagger$ & 9.17 & 0 & NCoop*Chardonnay & 0.13 & 3.550 \\
\hline Age & $0.02 *$ & 1.84 & 0.07 & Points & $0.12 \ddagger$ & $8.54 \quad 0$ \\
\hline Dry Style & $0.11 \ddagger$ & 10.4 & 0 & Age & 0.02 & 1.560 .12 \\
\hline Barrique & $0.54 \ddagger$ & 25.4 & 0 & Dry Style & $0.12 \ddagger$ & 11.10 \\
\hline Color & $0.17 \ddagger$ & 9.90 & 0 & Barrique & $0.56 \%$ & 26.20 \\
\hline Riesling & $0.16 \ddagger$ & 9.02 & 0 & Color & $0.16 \sharp$ & $8.77 \quad 0$ \\
\hline Gewürztraminer & $0.16 \ddagger$ & 7.56 & 0 & Quality Wine & -0.18 & $-14.0 \quad 0$ \\
\hline Chardonnay & $0.12 \ddagger$ & 3.66 & 0 & Kabinett & $-0.28 \ddagger$ & -21.20 \\
\hline Pinot Blanc & $0.08 \ddagger$ & 3.82 & 0 & Auslese & $0.35 \ddagger$ & $22.2 \quad 0$ \\
\hline Pinot Noir & $0.03 *$ & 1.77 & 0.08 & Beerenauslese & $0.98 \ddagger$ & 26.20 \\
\hline Dornfelder & $-0.09 \ddagger$ & -3.78 & 0 & TBA & $1.50 \ddagger$ & $21.7 \quad 0$ \\
\hline Lemberger & $0.12 \ddagger$ & 4.70 & 0 & Eiswein & $1.37 \ddagger$ & $44.0 \quad 0$ \\
\hline Ahr & $0.57 \ddagger$ & 9.00 & 0 & Ahr & $0.59 \ddagger$ & $9.28 \quad 0$ \\
\hline Baden & $0.35 \ddagger$ & 19.9 & 0 & Baden & $0.34 \ddagger$ & $18.6 \quad 0$ \\
\hline Franken & $0.40 \ddagger$ & 19.8 & 0 & Franken & $0.41 \%$ & 20.60 \\
\hline Hess.-Bergstr. & $0.21 \ddagger$ & 5.99 & 0 & Hess.-Bergstr. & $0.21 \%$ & $5.98 \quad 0$ \\
\hline Mittelrhein & $0.16 \ddagger$ & 3.40 & 0 & Mittelrhein & $0.15 \ddagger$ & 3.210 \\
\hline Mosel & $0.16 \ddagger$ & 7.07 & 0 & Mosel & 0.16 & $6.78 \quad 0$ \\
\hline Nahe & $0.23 \ddagger$ & 6.97 & 0 & Nahe & $0.24 \ddagger$ & $7.06 \quad 0$ \\
\hline Rheingau & $0.31 \ddagger$ & 6.47 & 0 & Rheingau & $0.30 \ddagger$ & $6.38 \quad 0$ \\
\hline Rheinhessen & $-0.07 \ddagger$ & -4.02 & 0 & Rheinhessen & -0.05 & $-3.04 \quad 0$ \\
\hline Saale Unstrut & $0.44 \ddagger$ & 12.1 & 0 & Saale Unstrut & $0.44 \ddagger$ & $12.1 \quad 0$ \\
\hline Sachsen & $0.74 \ddagger$ & 24.1 & 0 & Sachsen & $0.75 \ddagger$ & $23.9 \quad 0$ \\
\hline Württemberg & $0.15 \ddagger$ & 8.76 & 0 & Württemberg & $0.14 \ddagger$ & $7.98 \quad 0$ \\
\hline F-statistic & & $278.8^{*}$ & 0 & F-statistic & & $276.2^{\ddagger} \quad 0$ \\
\hline Wald F-stat. & & $253.5^{\ddagger}$ & 0 & Wald F-stat. & & $237.0^{\ddagger} \quad 0$ \\
\hline Adjusted R ${ }^{2}$ & & 0.741 & & Adjusted $\mathrm{R}^{2}$ & & 0.739 \\
\hline Observations & & 3593 & & Observations & & 593 \\
\hline
\end{tabular}

The symbols $\ddagger$, $\dagger$, and $*$ denote significance at the $1 \%, 5 \%$, and $10 \%$ level, respectively. 
Table 5. Summary of Results.

\begin{tabular}{|c|c|c|}
\hline Estimation & Hypothesis & Confirm Hypothesis \\
\hline Model 1 & 1.A Reputation & Yes \\
& 1.B Wine Quality & Yes \\
\hline Model 2 & $\begin{array}{c}\text { 2.A Quality Category } \\
\text { 2.B Variety }\end{array}$ & $\begin{array}{c}\text { Yes (except for Beerenauslese) } \\
\text { Yes (except for Lemberger \& Dornfelder) }\end{array}$ \\
\hline
\end{tabular}

are able to reap a price premium. Thus, we may also confirm hypothesis 2 .B except for two minor varieties. Our main results are summarized in Table 5.

\section{Discussion and conclusion}

In this paper, we provide some more empirical evidence from Germany which illustrates how cooperative and private wineries compete regarding product quality and reputation. A cooperative's reputation for quality wine production depends crucially on the quality variation of its grape supply from individual growers. Thus, wine quality may be more uncertain further downstream. In contrast, private (non-cooperative) wineries may be characterized by a higher degree of control within their production chains and thus may produce a more certain wine quality further downstream. The resulting reputation and wine quality effects on market prices are analyzed in this paper.

The estimated results in this paper exhibit expected signs and relative magnitudes [14] and allow us to interpret why wines from cooperative producers tend to receive lower quality premiums. The detailed analysis of our models allows us to interpret this result as well as to derive important strategic considerations for cooperative wine producers.

The results indicate that German cooperative wineries are not able to compete with private wineries both in terms of wine quality and reputation. As opposed to cooperatives in Alto Adige they have not lowered the uncertainty about their grape quality supply relative to private wineries such that their wine quality premium for disappears [4].

This paper supports the findings derived by SantosArteaga and Schamel [8] who showed that incentives regarding coordination and integration may determine if cooperatives are able to compete with private wineries regarding product quality and reputation. Cooperative success may be accomplished by minimizing the downstream uncertainty about wine quality through strict management of the grape supply further upstream. The data analyzed in this paper shows that at the moment this is not achieved by German cooperatives.

The empirical analyses performed in this paper largely confirm both hypotheses put forward. The estimated coefficients indicate that German cooperatives are unable to gain quality premium for all wine quality categories (except BA) and for distinct varieties such as Riesling. However, we estimate a cooperative premium for two lesser known German varieties: Lemberger and Dornfelder.

Currently, German cooperatives are unable to compete with private wineries both in terms of quality and reputation. This result supports the general observation that cooperatives typically compete on price within the German market as many of their wines are being sold in discount stores or large supermarkets. In terms of cooperative performance in a larger European context, this result is rule rather than the exception, as argued by Schamel [4]. In terms of this paper, we can argue that German cooperatives are stuck in the low quality corner of the quality category and variety spectrum. In order to get of there, it will be necessary to re-organize the cooperative management and its supply chain applying innovative measures in order to raise grape and wine quality.

\section{References}

[1] Sexton, R. J., Lavoie, N., 2001, "Food Processing and Distribution: An Industrial Organization Approach." (Chapter 15, Volume 1B) in Handbook of Agricultural Economics, edited by Gardner B. and G. Rausser, Elsevier, North Holland, 863-932.

[2] Hendrikse, G.W.J., 1998, Screening, Competition and the Choice of Marketing Cooperative as an Organizational Form, J Agricultural Economics, 49(2): 202-217.

[3] Hendrikse, G.W.J., 2007, On the Co-existence of Spot and Contract Markets: the Delivery Requirement as Contract Externality, European Review of Agricultural Economics, 34(2): 257-282.

[4] Schamel, G., 2014, Wine Quality, Reputation and Price: How Cooperatives and Private Wineries Compete? BIO Web of Conferences 3, 03008.

[5] Deutscher Raiffeisenverband, 2012, Entwicklung der Winzergenossenschaften. Historical data available at www.deutsche-winzergenossenschaften.de

[6] European Commission, 2013, Overview of the CAP Reform 2014-2020, Agricultural Policy Brief No. 5* December.

[7] Pennerstorfer, D., Weiss, C., 2013, "Product quality in the agri-food chain: Do cooperatives offer highquality wine?" European Review of Agricultural Economics, 40(1), pp. 143-162.

[8] Santos-Arteaga, F.J., Schamel, G., 2014, Organizational Form and Payoff Imbalances in an Aggrievement Model: Cooperatives vs. Markets. http : / / ssrn. com/abstract $=2460516$

[9] Schamel, G., 2003, "A Hedonic Pricing Model for German Wine." German Journal of Agricultural Economics - Agrarwirtschaft. Heft 5. pp. 247-54.

[10] Hoffmann, R., 2005, “Ownership Structure and Endogenous Quality Choice: Cooperatives versus Investor-Owned Firms," J Agricultural \& Food Industrial Organization, 3(2), Article 8. Available at www . bepress. com/jafio/vol3/iss $2 /$ art 8

[11] Hanf, J., Schweickert, E., 2014, "Cooperatives in the balance between retail and member interests: the challenges of the German cooperative sector." Journal of Wine Research, 25:32-44.

[12] Frick, B. 2004, "Does ownership matter? Empirical evidence from the German wine industry." Kyklos, 57:357-386.

[13] Schamel, G., 2010, "German Wine Cooperatives: Lower Reward for Quality?" Proceedings AIEA2 Congress: The Role of Cooperatives in the European Agro-food System. Bononia University Press, Bologna.

[14] Schamel, G., 2005, "German Wine: Measurement and Evaluation of Product Quality?" in Umweltund Produktqualität im Agrarbereich, Schriften der GeWiSoLa e.V., Band 40, p. 143-151. 